Research article

\title{
COMPARATIVE EVALUATION OF THE CYTOLOGICAL, HISTOPATHOLOGICAL AND IMMUNOHISTOCHEMICAL FINDINGS OF CANINE CUTANEOUS AND SUBCUTANEOUS MASSES
}

\author{
IPEK Volkan ${ }^{1,2 *}$, CANGUL I.Taci ${ }^{1}$, AKKOC Ahmet ${ }^{1}$ \\ ${ }^{1}$ Department of Pathology, Faculty of Veterinary Medicine, Bursa Uludağ University, Bursa, Turkey; \\ ${ }^{2}$ Department of Pathology, Faculty of Veterinary Medicine, Mehmet Akif Ersoy University, Burdur, \\ Turkey
}

(Received 09 August 2020, Accepted 08 February 2021)

In this study, we compared the cytological, histopathological, and immunohistochemical diagnoses of 71 canine cutaneous and subcutaneous masses. Cytological diagnoses included 56 tumors (21 mesenchymal, 15 epithelial, 16 round cell, four melanocytic), 13 inflammatory reactions, and two cysts. Of the 21 cytologically diagnosed mesenchymal tumors, three were later confirmed non-tumoral (hematoma, granulation tissue, fibroepithelial polyp). Thirteen out of 15 epithelial tumors were correctly diagnosed cytologically, whereas two cases were confirmed to be non-tumoral (fibroepithelial polyp, granulation tissue) after histopathological examination. One mast cell tumor was later confirmed as fibrous hyperplasia; diagnoses were correct in other round cell tumors. Cytological diagnoses were correct for all melanocytic tumors and cystic lesions. Five cases which had been cytologically diagnosed as inflammatory reactions were diagnosed as tumors (lymphoma, papilloma, sebaceous adenoma, and squamous cell carcinoma) after histopathological examination. Immunohistochemistry confirmed the histopathological diagnoses of all epithelial and round cell tumors, while the diagnoses of six mesenchymal tumors were changed after the immunohistochemical examination. The total accuracy of cytology in the diagnosis of tumoral/non-tumoral masses was $84.5 \%$, and the accuracy in the determination of benign/malignant behavior was $83 \%$. Diagnostic accordance between histopathology and immunohistochemistry was $86.6 \%$. High success rates obtained with cytological diagnoses prove that cytology is a reliable diagnostic tool. The main diagnostic challenge remains with mesenchymal tumors and tumors accompanied by inflammatory reactions. The results suggest that immunohistochemistry is fundamental for diagnoses of most mesenchymal tumors.

Keywords: Dog, cytology, histopathology, immunohistochemistry, skin, tumor

\section{INTRODUCTION}

Cytology is a labor- and cost-effective method that yields results in a very brief time compared to histopathology in the diagnosis of cutaneous and subcutaneous

\footnotetext{
*Corresponding author: e-mail: volkanipek@mehmetakif.edu.tr
} 
masses [1-3]. However, a proper sample cannot be obtained in many cases, and the knowledge and experience of the examiner directly affect the rate of accurate diagnosis. Since the tissue structure is not observed in cytology, histopathology remains an integral part of the diagnosis [3].

Numerous studies have been carried out to compare the cytological and histopathological diagnoses of both healthy and abnormal structures in humans [4-7] and in animals [812]. The accuracy rate has ranged between $70.5-91 \%$ in studies evaluating the reliability of cytology in the diagnosis of cutaneous and subcutaneous masses [8-10,12,13]. In a retrospective study conducted by Simeonov [14], the cytological slides of 300 cutaneous and subcutaneous palpable lesions from dogs were compared with histopathological slides. The total agreement rate between cytology and histopathology was $88.7 \%$, sensitivity was $90.47 \%$, specificity was $97.22 \%$, positive predictive value was $98.44 \%$, and the negative predictive value was $63.63 \%$.

In this study, we compared the cytological diagnoses of 71 cutaneous and subcutaneous masses with histopathological and (in some cases) immunohistochemical examination results. The predictive value of cytology for the differentiation of tumoural/nontumoural masses and benign/malignant nature was evaluated.

\section{MATERIAL AND METHODS}

A total of 71 masses were excised from the skin and subcutis of dogs, and the cytological, histopathological, and (in some cases) immunohistochemical staining results were compared. Approval for the study was obtained from the Animal Experiments Local Ethics Committee (decree no: B.30.2.ULU.0.8Z.00.00-13).

\section{Preparation and suitability of cytological slides}

Cytological slides were prepared by using fine-needle biopsy, impression smear, or scraping techniques [2] and stained with Hemacolor ${ }^{\mathrm{TM}}$ (Merck Millipore, Darmstadt, Germany). In cases in which a sample could not be collected with fine-needle biopsy, an impression smear was made on the cut surface of the masses after surgical removal. Scraping technique was used only in masses that yielded very low cellularity with fineneedle aspiration or impression. The suitability of the cytological slides was assessed according to a classification from a previous study [15] and all slides except those of poor quality (insufficient cell number, thick preparation, etc.) were included.

\section{Tissue processing for histopathology and immunohistochemistry}

Tissue samples from the masses were fixed in $10 \%$ neutral buffered formalin and were processed routinely; 3-5 $\mu \mathrm{m}$ thick sections were stained with hematoxylin-eosin (Merck Millipore). Information about the primary antibodies is summarized in Table 1. All antibodies were known to cross-react with canine tissues, as confirmed with previous 
studies or indicated by the manufacturer. Cases from our archives with confirmed diagnoses were used as the positive control, while negative controls were generated by applying PBS instead of the primary antibody.

Table 1. Information about the antibodies

\begin{tabular}{|c|c|c|c|c|c|c|}
\hline Antibody & $\begin{array}{l}\text { Producer and } \\
\text { catalogue } \\
\text { number }\end{array}$ & Origin & Clone & Dilution & $\begin{array}{l}\text { Incubation } \\
\text { time }\end{array}$ & Pre-treatment \\
\hline CD3 & Dako, M7254 & $\begin{array}{l}\text { Mouse } \\
\text { anti-human }\end{array}$ & F7.2.38 & $1: 25$ & Overnight & $\begin{array}{l}\text { Citrate buffer, } \\
\text { pH 6, autoclave }\end{array}$ \\
\hline CD18 & Dr. Peter Moore, - & $\begin{array}{l}\text { Mouse } \\
\text { anti-canine }\end{array}$ & CA16.3C10 & $1: 20$ & $60 \mathrm{~min}$ & $\begin{array}{l}\text { Citrate buffer, } \\
\text { pH 6, autoclave }\end{array}$ \\
\hline $\mathrm{CD} 20$ & $\begin{array}{l}\text { Thermo Scientific, } \\
\text { RB-9013-P }\end{array}$ & $\begin{array}{l}\text { Rabbit } \\
\text { anti-human }\end{array}$ & Polyclonal & $1: 300$ & $120 \mathrm{~min}$ & - \\
\hline CD31 & Dako, M0823 & $\begin{array}{l}\text { Mouse } \\
\text { anti-human }\end{array}$ & $\mathrm{JC} 70 \mathrm{~A}$ & $1: 20$ & $60 \mathrm{~min}$ & $\begin{array}{l}\text { Citrate buffer, } \\
\text { pH 6, autoclave }\end{array}$ \\
\hline CD204 & $\begin{array}{l}\text { TransGenic, } \\
\text { KT022 }\end{array}$ & $\begin{array}{l}\text { Mouse } \\
\text { anti-human }\end{array}$ & SRA-E5 & $1: 800$ & Overnight & $\begin{array}{l}\text { Citrate buffer, } \\
\text { pH 6, autoclave }\end{array}$ \\
\hline Cytokeratin & Dako, M3515 & $\begin{array}{l}\text { Mouse } \\
\text { anti-human }\end{array}$ & AE1-AE3 & $1: 100$ & $60 \mathrm{~min}$ & $\begin{array}{l}\text { Citrate buffer, } \\
\text { pH 6, autoclave }\end{array}$ \\
\hline Desmin & Dako, M0760 & $\begin{array}{l}\text { Mouse } \\
\text { anti-human }\end{array}$ & D33 & $1: 100$ & Overnight & $\begin{array}{l}\text { EDTA buffer, } \\
\text { pH 9, autoclave }\end{array}$ \\
\hline E-cadherin & Dako, M3612 & $\begin{array}{l}\text { Mouse } \\
\text { anti-human }\end{array}$ & $\mathrm{NCH}-38$ & $1: 100$ & $60 \mathrm{~min}$ & $\begin{array}{l}\text { Citrate buffer, } \\
\text { pH 6, autoclave }\end{array}$ \\
\hline $\begin{array}{l}\text { MART1/ } \\
\text { Melan-A }\end{array}$ & $\begin{array}{l}\text { Thermo Scientific, } \\
\text { MS-799-PO }\end{array}$ & $\begin{array}{l}\text { Mouse } \\
\text { anti-human }\end{array}$ & A103 & $1: 200$ & $60 \mathrm{~min}$ & $\begin{array}{l}\text { EDTA buffer, } \\
\text { pH 9, autoclave }\end{array}$ \\
\hline $\begin{array}{l}\text { Neuro- } \\
\text { filament }\end{array}$ & Dako, M0762 & $\begin{array}{l}\text { Mouse } \\
\text { anti-human }\end{array}$ & $2 \mathrm{~F} 11$ & $1: 100$ & $60 \mathrm{~min}$ & $\begin{array}{l}\text { Citrate buffer, } \\
\text { pH 6, autoclave }\end{array}$ \\
\hline S100 & Dako, Z0311 & $\begin{array}{l}\text { Rabbit } \\
\text { anti-cow }\end{array}$ & Polyclonal & $1: 400$ & $45 \min$ & $\begin{array}{l}\text { Citrate buffer, } \\
\text { pH 6, autoclave }\end{array}$ \\
\hline $\begin{array}{l}\text { Sarcomeric } \\
\text { actin }\end{array}$ & Dako, M0874 & $\begin{array}{l}\text { Mouse } \\
\text { anti-rabbit }\end{array}$ & Alpha-Sr-1 & $1: 100$ & Overnight & $\begin{array}{l}\text { Citrate buffer, } \\
\text { pH 6, autoclave }\end{array}$ \\
\hline SMA & Dako, M0851 & $\begin{array}{l}\text { Mouse } \\
\text { anti-human }\end{array}$ & $1 \mathrm{~A} 4$ & $1: 100$ & Overnight & $\begin{array}{l}\text { EDTA buffer, } \\
\text { pH 9, autoclave }\end{array}$ \\
\hline Tryptase & Dako, M7052 & $\begin{array}{l}\text { Mouse } \\
\text { anti-human }\end{array}$ & AA1 & $1: 200$ & $45 \mathrm{~min}$ & $\begin{array}{l}\text { Citrate buffer, } \\
\text { pH 6, autoclave }\end{array}$ \\
\hline Vimentin & Dako, M7020 & $\begin{array}{l}\text { Mouse } \\
\text { anti-cow }\end{array}$ & Vim 3B4 & $1: 200$ & $60 \mathrm{~min}$ & $\begin{array}{l}\text { Citrate buffer, } \\
\text { pH 6, autoclave }\end{array}$ \\
\hline
\end{tabular}

\section{Examination of the slides}

The cytological slides were examined by one pathologist (VI), histopathological and immunohistochemical slides were additionally evaluated by two different pathologists with consultation (ITC, AA), who were uninformed about the cytological diagnosis. 


\section{Comparison of findings}

Classification of epithelial [16], mesenchymal [17-19], and round cell tumors [20,21] were made according to previous reports.

Three main criteria were sought while determining the accuracy of cytology: accuracy in diagnosing whether the mass was a tumor or non-tumor, and if tumoral whether it had a benign or malignant character. In cases in which the diagnosis of a tumor was changed to another tumor after the histopathological examination (e.g., diagnosis of a trichoblastoma was changed as sebaceous epithelioma), statistical analysis was also performed. Finally, the accuracy rate of histopathological diagnosis was calculated after the final diagnoses were determined with immunohistochemical staining.

\section{Statistics}

Sensitivity, specificity, positive predictive value, negative predictive value, and total accuracy rate for cytology were determined as reported previously [22,23] and according to the following equations (Table 2):

Sensitivity (true positive rate) $=\mathrm{TP} / \mathrm{TP}+\mathrm{FN}$; Specificity (true negative rate) $=\mathrm{TN} /$ $\mathrm{TN}+\mathrm{FP}$; Positive predictive value $(\mathrm{PPV})=\mathrm{TP} / \mathrm{TP}+\mathrm{FP} ;$ Negative predictive value $(\mathrm{NPV})=\mathrm{TN} / \mathrm{TN}+\mathrm{FN} ;$ Total accuracy $=\mathrm{TP}+\mathrm{TN} / \mathrm{N}$.

Table 2. The method used in calculating the accuracy rate

\begin{tabular}{lccc}
\hline \multirow{2}{*}{ Cytological diagnosis } & \multicolumn{3}{c}{ Histopathological diagnosis* } \\
\cline { 2 - 4 } & Tumoral & Non-tumoral & Total \\
\hline Tumoral & TP & FP & TP+FP \\
Non-tumoral & FN & TN & FN+TN \\
Total & TP+FN & FP+TN & N=TP+TN+FP+FN \\
\hline
\end{tabular}

*TP: True positive, FP: False positive, FN: False negative, TN: True negative, N: Total case number. Sensitivity (true positive rate) $=\mathrm{TP} / \mathrm{TP}+\mathrm{FN}$; Specificity $($ true negative rate) $=\mathrm{TN} / \mathrm{TN}+\mathrm{FP}$; Positive predictive value $(\mathrm{PPV})=\mathrm{TP} / \mathrm{TP}+\mathrm{FP} ;$ Negative predictive value $(\mathrm{NPV})=\mathrm{TN} / \mathrm{TN}+\mathrm{FN}$; Total accuracy $=\mathrm{TP}+\mathrm{TN} / \mathrm{N}$.

\section{RESULTS}

\section{Comparison of cytological and histopathological findings}

Cytological examination of 71 masses revealed that 56 masses were tumoral (21 mesenchymal, 15 epithelial, 16 round cell, four melanocytic), 13 were inflammatory, and two were cystic lesions. Histopathological examination revealed 55 tumors (17 mesenchymal, 17 epithelial, 17 round cell, four melanocytic), eight inflammatory reactions, six tumor-like/hyperplastic changes, and two cystic lesions (Tables 3-5). The accuracy rate of cytological diagnosis in determining tumors and non-tumors were as follows: Sensitivity (true positive rate) $=90.9 \%$, specificity (true negative rate) $=62.5$ $\%$, positive predictive value $=89.2 \%$, negative predictive value $=66.6 \%$, total accuracy $=84.5 \%$ (Table 6 ). 
Table 3. Comparison of the cytological, histopathological, and immunohistochemical diagnoses of 21 mesenchymal tumors. The classification of the cases is based on the cytological diagnosis.

\begin{tabular}{|c|c|c|c|}
\hline Cytological diagnosis & $\begin{array}{l}\text { Histopathological } \\
\text { diagnosis }\end{array}$ & $\begin{array}{l}\text { Immuno- } \\
\text { histochemical } \\
\text { diagnosis* }\end{array}$ & Markers** \\
\hline Hemangioma (1) & Hemangioma (1) & Hemangioma (1) & CD31+ \\
\hline Hemangiosarcoma (1) & $\begin{array}{l}\text { Organizing hematoma } \\
\text { (1) }\end{array}$ & --- & \\
\hline $\begin{array}{l}\text { Hemangiopericytoma } \\
\text { (1) }\end{array}$ & Fibroma (1) & Rhabdomyoma (1) & $\begin{array}{l}\text { S100+, SRCA+, Vim+ } \\
\text { CD31-, Des-, Mel-A-, } \\
\text { Neu-, CK-, SMA- }\end{array}$ \\
\hline Lipoma (6) & Lipoma (6) & --- & \\
\hline Myxoma (1) & Myxoid PNST*** (1) & $\begin{array}{l}\text { Myxoid PNST*** } \\
\text { (1) }\end{array}$ & $\begin{array}{l}\text { S100+, Vim+ } \\
\text { CD31-, Des-, Mel-A-, } \\
\text { Neu-, CK-, SMA-, } \\
\text { SRCA- }\end{array}$ \\
\hline \multirow{2}{*}{$\begin{array}{l}\text { Malignant fibrous } \\
\text { histiocytoma (2) }\end{array}$} & Malignant histiocytosis (1) & $\begin{array}{l}\text { Malignant } \\
\text { histiocytosis (1) }\end{array}$ & $\begin{array}{l}\text { CD18+, CD204+, } \\
\text { E-cad+, Vim+ } \\
\text { CD3-, CD20-, Tryp- }\end{array}$ \\
\hline & Trichoepithelioma (1) & $\begin{array}{l}\text { Trichoepithelioma } \\
\text { (1) }\end{array}$ & $\begin{array}{l}\text { CK+ } \\
\text { Vim- }\end{array}$ \\
\hline \multirow{4}{*}{$\begin{array}{l}\text { Benign mesenchymal } \\
\text { tumor (4) }\end{array}$} & Perineuroma (1) & Perineuroma (1) & $\begin{array}{l}\text { S100+, Vim+ } \\
\text { CD31-, Des-, Mel-A-, } \\
\text { Neu-, CK-, SMA-, } \\
\text { SRCA- }\end{array}$ \\
\hline & Granulation tissue (1) & --- & \\
\hline & Haemangioma (1) & $\begin{array}{l}\text { Benign } \\
\text { mesenchymal } \\
\text { tumor (1) }\end{array}$ & $\begin{array}{l}\text { Vim+ } \\
\text { S100-, CD31-, Des-, } \\
\text { Mel-A-, Neu-, CK-, } \\
\text { SMA-, SRCA- }\end{array}$ \\
\hline & $\begin{array}{l}\text { Perivascular wall tumor } \\
\text { (1) }\end{array}$ & $\begin{array}{l}\text { Haemangio- } \\
\text { pericytoma (1) }\end{array}$ & $\begin{array}{l}\text { S100+, Vim+ } \\
\text { CD31-, Des-, Mel-A-, } \\
\text { Neu-, CK-, SMA-, } \\
\text { SRCA- }\end{array}$ \\
\hline \multirow{5}{*}{$\begin{array}{l}\text { Malignant } \\
\text { mesenchymal tumor } \\
\text { (5) }\end{array}$} & $\begin{array}{l}\text { Malignant fibrous } \\
\text { histiocytoma (1) }\end{array}$ & $\begin{array}{l}\text { Malignant fibrous } \\
\text { histiocytoma (1) }\end{array}$ & $\begin{array}{l}\text { CD204+, Vim+ } \\
\text { CD3-, CD18-, CD20-, } \\
\text { E-Cad-, Tryp- }\end{array}$ \\
\hline & $\begin{array}{l}\text { Perivascular wall tumor } \\
\text { (1) }\end{array}$ & $\begin{array}{l}\text { Undifferentiated } \\
\text { sarcoma (1) }\end{array}$ & $\begin{array}{l}\text { Vim+ } \\
\text { S100-, CD31-, Des-, } \\
\text { Mel-A-, Neu-, CK-, } \\
\text { SMA-, SRCA- }\end{array}$ \\
\hline & $\begin{array}{l}\text { Undifferentiated } \\
\text { sarcoma (1) }\end{array}$ & $\begin{array}{l}\text { Hemangio- } \\
\text { pericytoma (1) }\end{array}$ & $\begin{array}{l}\text { SMA+, SRCA+, Vim+ } \\
\text { CD31-, Des-, Mel-A-, } \\
\text { Neu-, S100- }\end{array}$ \\
\hline & $\begin{array}{l}\text { Undifferentiated } \\
\text { sarcoma (1) }\end{array}$ & $\begin{array}{l}\text { Undifferentiated } \\
\text { sarcoma (1) }\end{array}$ & $\begin{array}{l}\text { Vim+ } \\
\text { S100-, CD31-, Des-, } \\
\text { Mel-A-, Neu-, CK-, } \\
\text { SMA-, SRCA- }\end{array}$ \\
\hline & Fibroepithelial polyp (1) & & \\
\hline
\end{tabular}

*Immunohistochemical staining was not performed in "---" marked cases. Incompatible diagnoses are written with bold characters. **SRCA: Sarcomeric actin, Vim: Vimentin, Des: Desmin, Mel-A: Melan-A, Neu: Neurofilament, CK: Cytokeratin, SMA: Smooth muscle actin, E-Cad: E-Cadherin, Tryp: Tryptase. ***PNST: Peripheral nerve sheath tumor 
Table 4. Comparison of the cytological, histopathological, and immunohistochemical diagnoses of 15 epithelial tumors. Classification of the cases is based on cytological diagnosis.

\begin{tabular}{|c|c|c|c|}
\hline Cytological diagnosis & $\begin{array}{l}\text { Histopathological } \\
\text { diagnosis }\end{array}$ & $\begin{array}{l}\text { Immunohistochemical } \\
\text { diagnosis* }\end{array}$ & Markers** \\
\hline Papilloma (4) & Papilloma (4) & Papilloma (4) & $\begin{array}{l}\text { CK+ } \\
\text { Vim- }\end{array}$ \\
\hline Fibropapilloma (1) & $\begin{array}{l}\text { Fibroepithelial } \\
\text { polyp (1) }\end{array}$ & --- & \\
\hline \multirow{3}{*}{ Trichoblastoma (5) } & Trichoblastoma (3) & Trichoblastoma (3) & $\begin{array}{l}\mathbf{C K}+ \\
\text { Vim- }\end{array}$ \\
\hline & $\begin{array}{l}\text { Sebaceous } \\
\text { epithelioma (1) }\end{array}$ & $\begin{array}{l}\text { Sebaceous epithelioma } \\
\text { (1) }\end{array}$ & $\begin{array}{l}\text { CK+ } \\
\text { Vim- }\end{array}$ \\
\hline & $\begin{array}{l}\text { Perivascular wall } \\
\text { tumor (1) }\end{array}$ & $\begin{array}{l}\text { Undifferentiated } \\
\text { sarcoma (1) }\end{array}$ & $\begin{array}{l}\text { Vim+ } \\
\text { S100-, CD31-, Des-, } \\
\text { Mel-A-, Neu-, CK-, SMA-, } \\
\text { SRCA- }\end{array}$ \\
\hline Carcinoma (1) & $\begin{array}{l}\text { Sebaceous } \\
\text { adenocarcinoma (1) }\end{array}$ & $\begin{array}{l}\text { Sebaceous } \\
\text { adenocarcinoma (1) }\end{array}$ & $\begin{array}{l}\text { CK+ } \\
\text { Vim+ }\end{array}$ \\
\hline Adenocarcinoma (1) & $\begin{array}{l}\text { Chronic } \\
\text { inflammatory } \\
\text { reaction (1) } \\
\end{array}$ & --- & \\
\hline $\begin{array}{l}\text { Perianal gland adenoma } \\
\text { (1) }\end{array}$ & $\begin{array}{l}\text { Perianal gland } \\
\text { epithelioma (1) }\end{array}$ & $\begin{array}{l}\text { Perianal gland } \\
\text { epithelioma (1) }\end{array}$ & $\begin{array}{l}\text { CK+ } \\
\text { Vim- }\end{array}$ \\
\hline $\begin{array}{l}\text { Perianal gland } \\
\text { adenocarcinoma (1) }\end{array}$ & $\begin{array}{l}\text { Perianal gland } \\
\text { adenocarcinoma (1) }\end{array}$ & $\begin{array}{l}\text { Perianal gland } \\
\text { adenocarcinoma (1) }\end{array}$ & $\begin{array}{l}\text { CK+ } \\
\text { Vim- }\end{array}$ \\
\hline Sebaceous adenoma (1) & $\begin{array}{l}\text { Sebaceous adenoma } \\
\text { (1) }\end{array}$ & Sebaceous adenoma (1) & $\begin{array}{l}\text { CK+ } \\
\text { Vim- }\end{array}$ \\
\hline
\end{tabular}

*Immunohistochemical staining was not performed in "--." marked cases. Incompatible diagnoses are written with bold characters.

${ }^{* *}$ CK: Cytokeratin, Vim: Vimentin, Des: Desmin, Mel-A: Melan-A, Neu: Neurofilament, SMA: Smooth muscle actin, SRCA: Sarcomeric actin 
Table 5. Comparison of the cytological, histopathological, and immunohistochemical diagnoses of 16 round cell tumours, 4 melanocytic tumours, 13 inflammatory conditions, and 2 cystic lesions. Classification of the cases is based on cytological diagnosis.

\begin{tabular}{llll}
\hline Cytological diagnosis & $\begin{array}{l}\text { Histopathological } \\
\text { diagnosis }\end{array}$ & $\begin{array}{l}\text { Immuno- } \\
\text { histochemical } \\
\text { diagnosis* }\end{array}$ & Markers** \\
\hline Histiocytoma (3) & Histiocytoma (3) & Histiocytoma (3) & $\begin{array}{l}\text { CD18+ } \\
\text { CD3-, CD20-, CD204-, } \\
\text { E-Cad-, Tryp- }\end{array}$ \\
\hline Histiocytoma (1) & Histiocytoma (1) & Histiocytoma (1) & $\begin{array}{l}\text { CD18+, E-Cad+ } \\
\text { CD3-, CD20-, CD204-, } \\
\text { Tryp- }\end{array}$ \\
\hline Histiocytic sarcoma (3) & Histiocytic sarcoma (3) & $\begin{array}{l}\text { Histiocytic sarcoma } \\
(3)\end{array}$ & $\begin{array}{l}\text { CD18+, CD204+, } \\
\text { E-Cad+, Vim+ } \\
\text { CD3-, CD20-, Tryp- }\end{array}$ \\
\hline Lymphoma (1) & Lymphoma (1) & Lymphoma (1) & $\begin{array}{l}\text { CD3+, CD18+ } \\
\text { CD20-, E-Cad-, Tryp- }\end{array}$ \\
\hline Mastocytoma (8) & Mastocytoma (7) & Mastocytoma (7) & Tryp+ \\
\cline { 2 - 4 } & $\begin{array}{l}\text { Fibrous hyperplasia } \\
(1)\end{array}$ & - & \\
\hline
\end{tabular}

Melanocytic tumours (4)

\begin{tabular}{ll}
\hline Malignant melanoma (1) & $\begin{array}{l}\text { Malignant melanoma } \\
(1)\end{array}$ \\
\hline Melanocytoma (3) & Melanocytoma (2) \\
\cline { 2 - 2 } & $\begin{array}{l}\text { Malignant melanoma } \\
\text { (1) }\end{array}$
\end{tabular}

Inflammatory conditions (13)

\begin{tabular}{llll}
\hline $\begin{array}{l}\text { Malassezia dermatitis } \\
\text { (1) }\end{array}$ & $\begin{array}{l}\text { Epitheliotropic } \\
\text { lymphoma (mycosis } \\
\text { fungoides) (1) }\end{array}$ & Null lymphoma (1) & $\begin{array}{l}\text { CD18+ } \\
\text { CD3-, CD20-, E-Cad-, } \\
\text { Tryp- }\end{array}$ \\
\hline & $\begin{array}{l}\text { Inflammatory reaction } \\
(7)\end{array}$ & -- & \\
\cline { 2 - 4 } & Papilloma (1) & Papilloma (1) & $\begin{array}{l}\text { CK+ } \\
\text { Vim- }\end{array}$ \\
\cline { 2 - 4 } $\begin{array}{l}\text { Inflammatory reaction } \\
\text { (12) }\end{array}$ & $\begin{array}{l}\text { Sebaceous } \\
\text { hyperplasia (1) }\end{array}$ & --- & \\
\cline { 2 - 4 } & $\begin{array}{l}\text { Sebaceous adenoma } \\
(\mathbf{1})\end{array}$ & $\begin{array}{l}\text { Sebaceous } \\
\text { adenoma (1) }\end{array}$ & $\begin{array}{l}\text { CK+ } \\
\text { Vim- }\end{array}$ \\
\cline { 2 - 4 } & $\begin{array}{l}\text { Squamous cell } \\
\text { carcinoma (2) }\end{array}$ & $\begin{array}{l}\text { Squamous cell } \\
\text { carcinoma (2) }\end{array}$ & $\begin{array}{l}\text { CK+ } \\
\text { Vim- }\end{array}$ \\
\hline Cystic lesions (2) & & & \\
\hline $\begin{array}{l}\text { Epidermal inclusion } \\
\text { cyst (2) }\end{array}$ & Epidermoid cyst (2) & -- & \\
\hline
\end{tabular}

*Immunohistochemical staining was not performed in "---" marked cases. Incompatible diagnoses are written with bold characters.

** E-Cad: E-Cadherin, Tryp: Tryptase, Vim: Vimentin, CK: Cytokeratin 
Table 6. Number of cases for tumoral and non-tumoral comparison

\begin{tabular}{lccc}
\hline \multirow{2}{*}{ Cytological diagnosis } & \multicolumn{3}{c}{ Histopathological diagnosis* } \\
\cline { 2 - 4 } & Tumoral & Non-tumoral & Total \\
\hline Tumoral & $50(\mathrm{TP})$ & $6(\mathrm{FP})$ & 56 \\
Non-tumoral & $5(\mathrm{FN})$ & $10(\mathrm{TN})$ & 15 \\
Total & 55 & 16 & $71(\mathrm{~N})$ \\
\hline
\end{tabular}

*TP: True positive, FP: False positive, FN: False negative, TN: True negative, N: Total case number Accuracy rate: $84.5 \%(\mathrm{TP}+\mathrm{TN} / \mathrm{N})$

Histopathological examination revealed a papilloma which was cytologically diagnosed as inflammatory reaction. Two trichoblastoma diagnoses in cytology was changed to sebaceous epithelioma and perivascular wall tumor, and in one case, malignant fibrous histiocytoma diagnosis in cytology was changed as trichoepithelioma after histopathological examination. In two cases, in which inflammatory reaction diagnosis was made cytologically, squamous cell carcinoma diagnoses were made
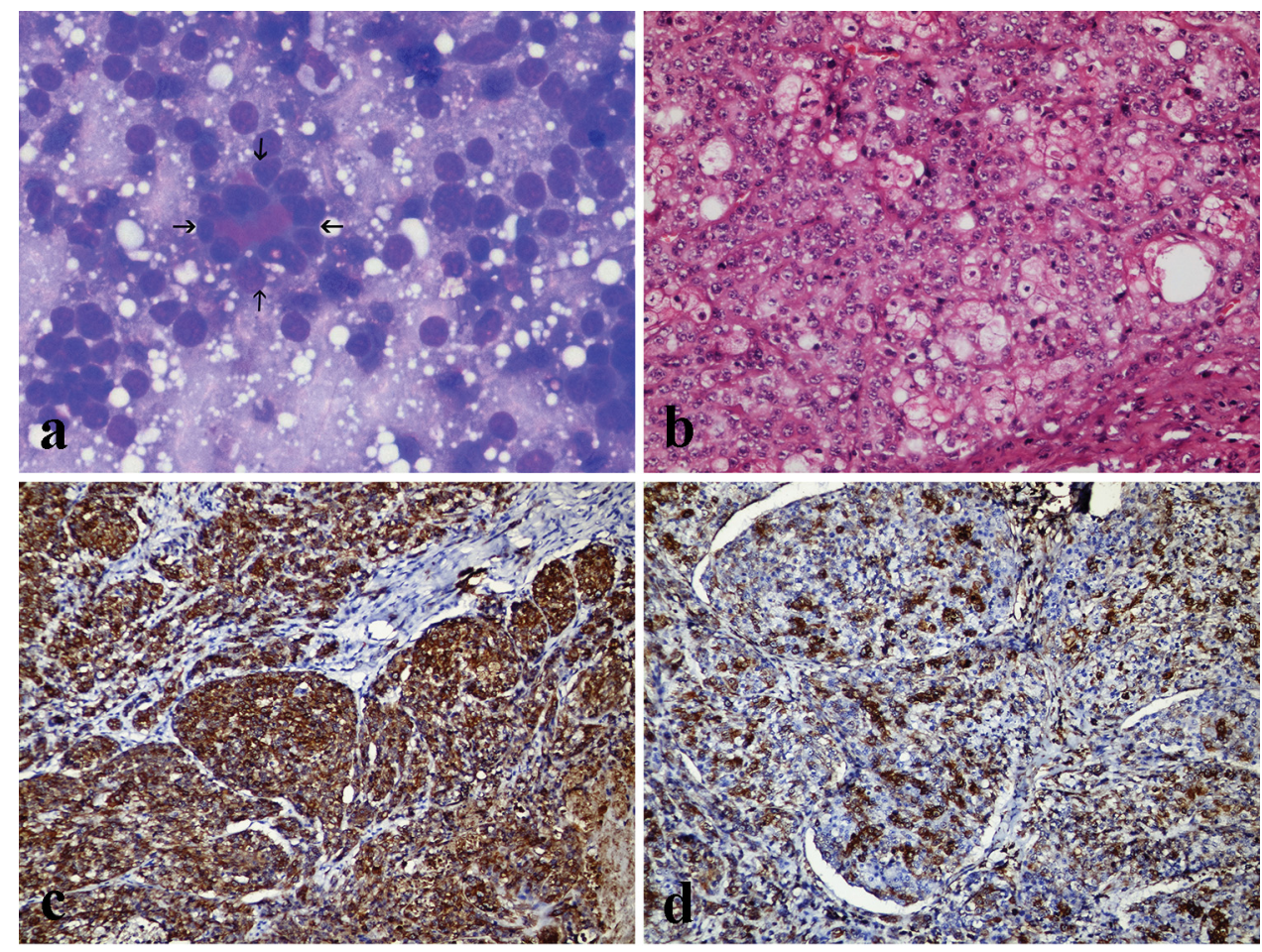

Figure 1. Sebaceous adenocarcinoma (a) Glandular epithelial cells showing adenoid formation (arrows) and mild anisokaryosis with abundant vacuoles and indistinct cytoplasmic borders, Hemacolor, x400. (b) Atypical epithelial cells having ample mitotic figures and vacuolated cytoplasms, Haematoxylin-Eosin, x200. (c) Cytokeratin positivity and (d) vimentin positivity in tumoral cells, avidin-biotin complex method, DAB chromogen, x200. 
after histopathological examination. A diagnosis of perianal gland adenoma was changed to perianal gland epithelioma histopathologically. In one case, cytologically, an inflammatory reaction was diagnosed due to the existence of neutrophils, but this diagnosis was changed as sebaceous hyperplasia/adenoma after histopathological examination. One case (Fig. 1a) that was cytologically diagnosed as carcinoma was histopathologically diagnosed as sebaceous adenocarcinoma (Fig. 1b).

A melanocytoma diagnosis in cytology was changed as malignant melanoma after histopathological examination. Another malignant melanoma diagnosis by cytology was compatible with histopathological diagnosis.

Diagnoses of benign mesenchymal tumor, malignant mesenchymal tumor, and trichoblastoma in cytology were changed as perivascular wall tumor after histopathology. In two cases, benign mesenchymal tumor diagnoses were hemangioma and perineuroma after histopathology. Hemangiopericytoma diagnosis in cytology was changed as fibroma after histopathology. Malignant mesenchymal tumor diagnosis in cytology was malignant fibrous histiocytoma after histopathology. Cytologically malignant mesenchymal tumor diagnosis in a case (Fig. 2a) was changed as undifferentiated sarcoma at histopathology (Fig. 2b). Myxoma diagnosis in the
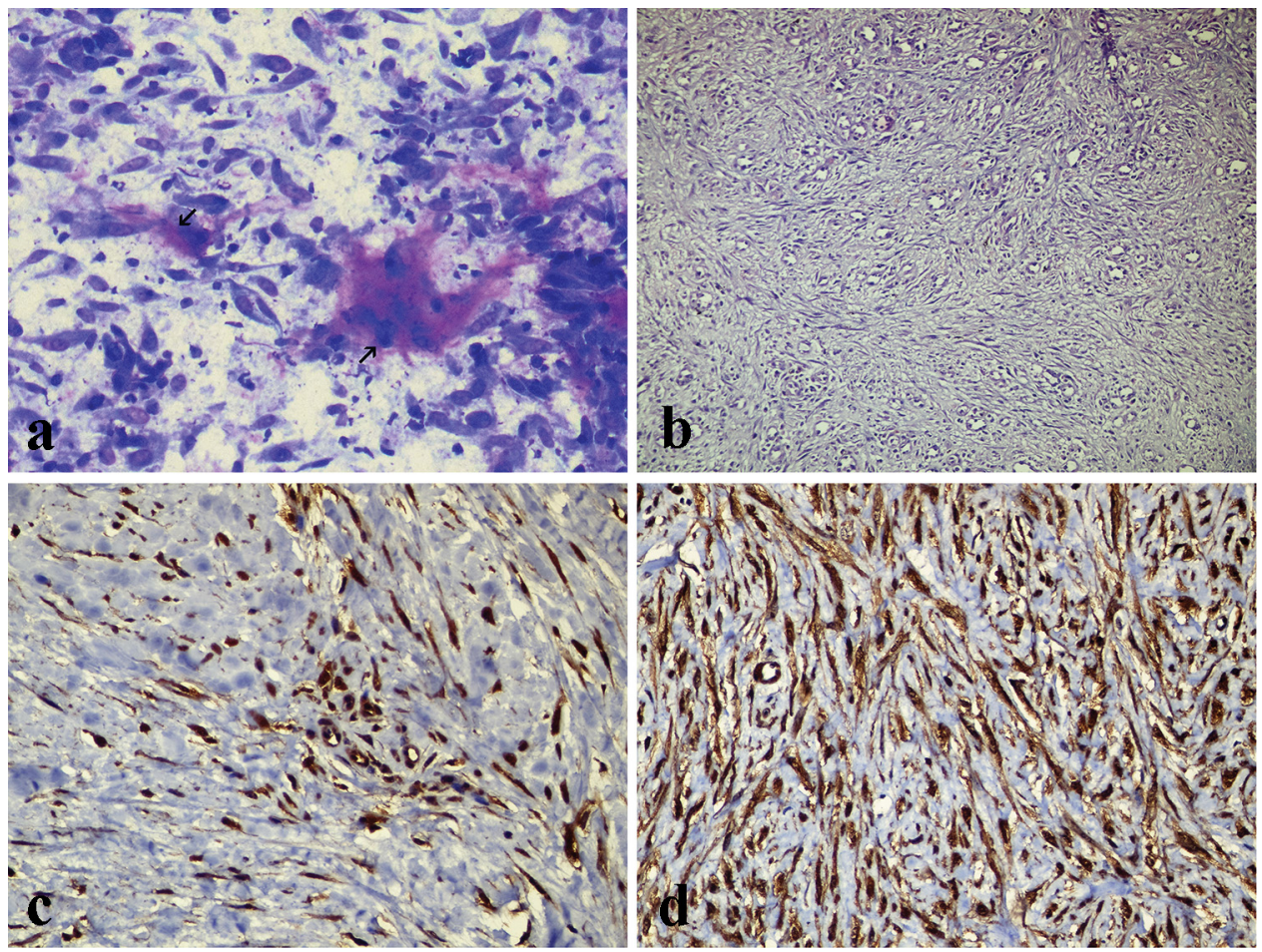

Figure 2. Haemangiopericytoma. (a) Atypical spindle cells with eosinophilic matrix (arrows), Hemacolor, x200. (b) Spindle cell proliferation around vessels, Haematoxylin-Eosin, x200. (c) SRCA positivity and (d) SMA positivity in tumoral cells, avidin-biotin complex method, DAB chromogen, $\mathrm{x} 400$. 
cytological examination (Fig. 3a) was changed as myxoid peripheral nerve sheath tumor (PNST) after histopathology (Fig. 3b).
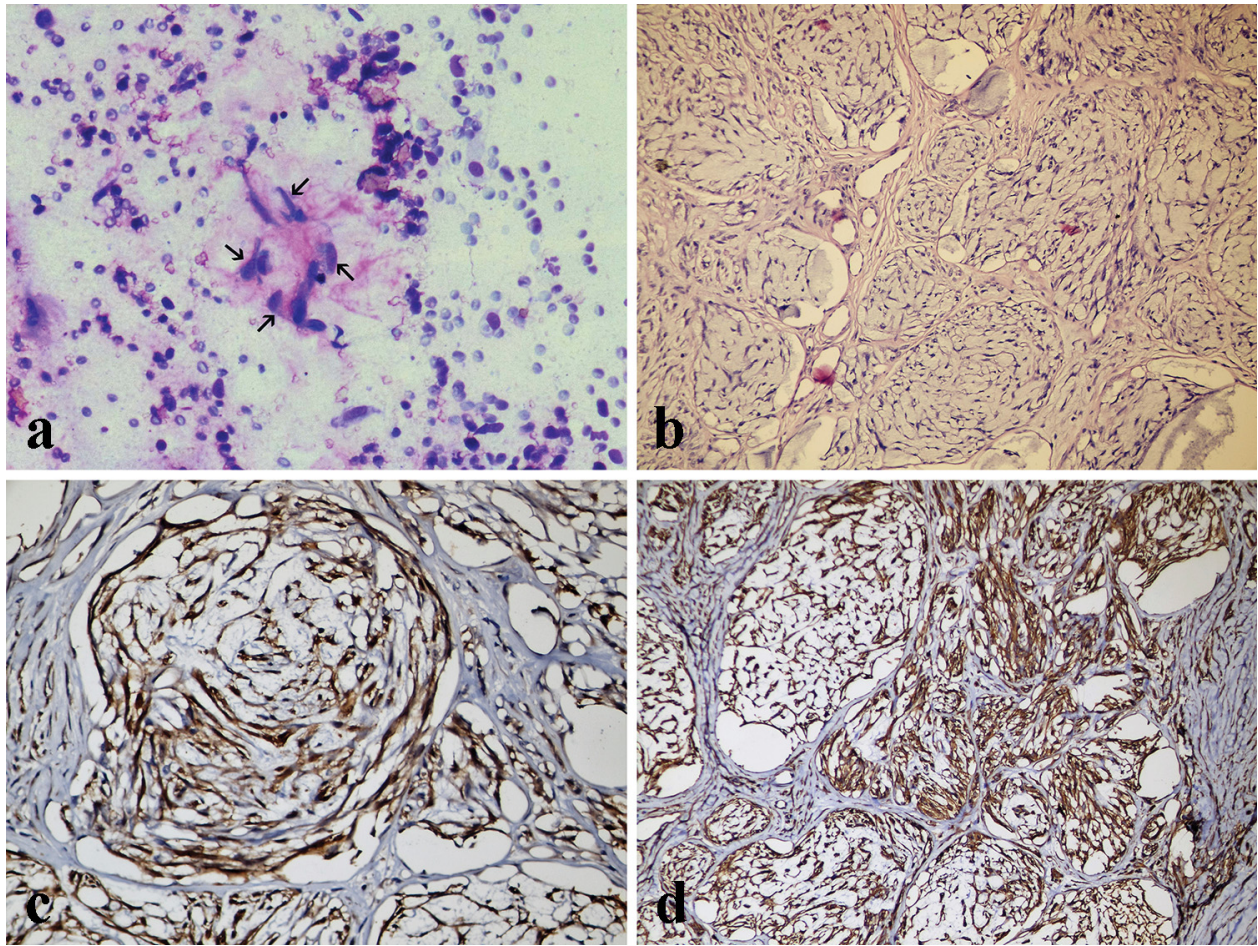

Figure 3. Myxoid peripheral nerve sheath tumor (PNST). (a) Spindle cells above eosinophilic matrix (arrows), Hemacolor, x200. (b) Round cell clusters formed by spindle cell proliferation consisting of lightly basophilic mucinous material, Haematoxylin-Eosin, x200. (c) S100 positivity and (d) Vimentin positivity in tumoral cells, avidin-biotin complex method, DAB chromogen, $\mathrm{x} 400$.

In a case which was cytologically diagnosed as mastocytoma, histopathological diagnosis was made as fibrous hyperplasia due to intense fibrous tissue hyperplasia with scattered mast cells in the dermis. Cytological and histopathological diagnoses were compatible in four histiocytomas (Figs. 4a and 4b) and three histiocytic sarcomas (Figs. 5a and 5b). In a case diagnosed as lymphoma, cytological and histopathological diagnoses were compatible. In another case, cytology revealed numerous yeasts resulting in a diagnosis of Malassezia dermatitis, but the final diagnosis after histopathology was epitheliotrophic lymphoma associated with Malassezia. Malignant fibrous histiocytoma diagnosis in cytology (Fig. 6a) was changed as malignant histiocytosis in histopathology (Fig. 6b).

Seven inflammatory reaction diagnoses cytologically were compatible with histopathological diagnoses. In a case, cytologically numerous atypical large epithelial cells with abundant cytoplasmic vacuoles were observed, and adenocarcinoma was 
diagnosed, but after histopathological examination, diagnosis was changed as chronic granulomatous reaction.
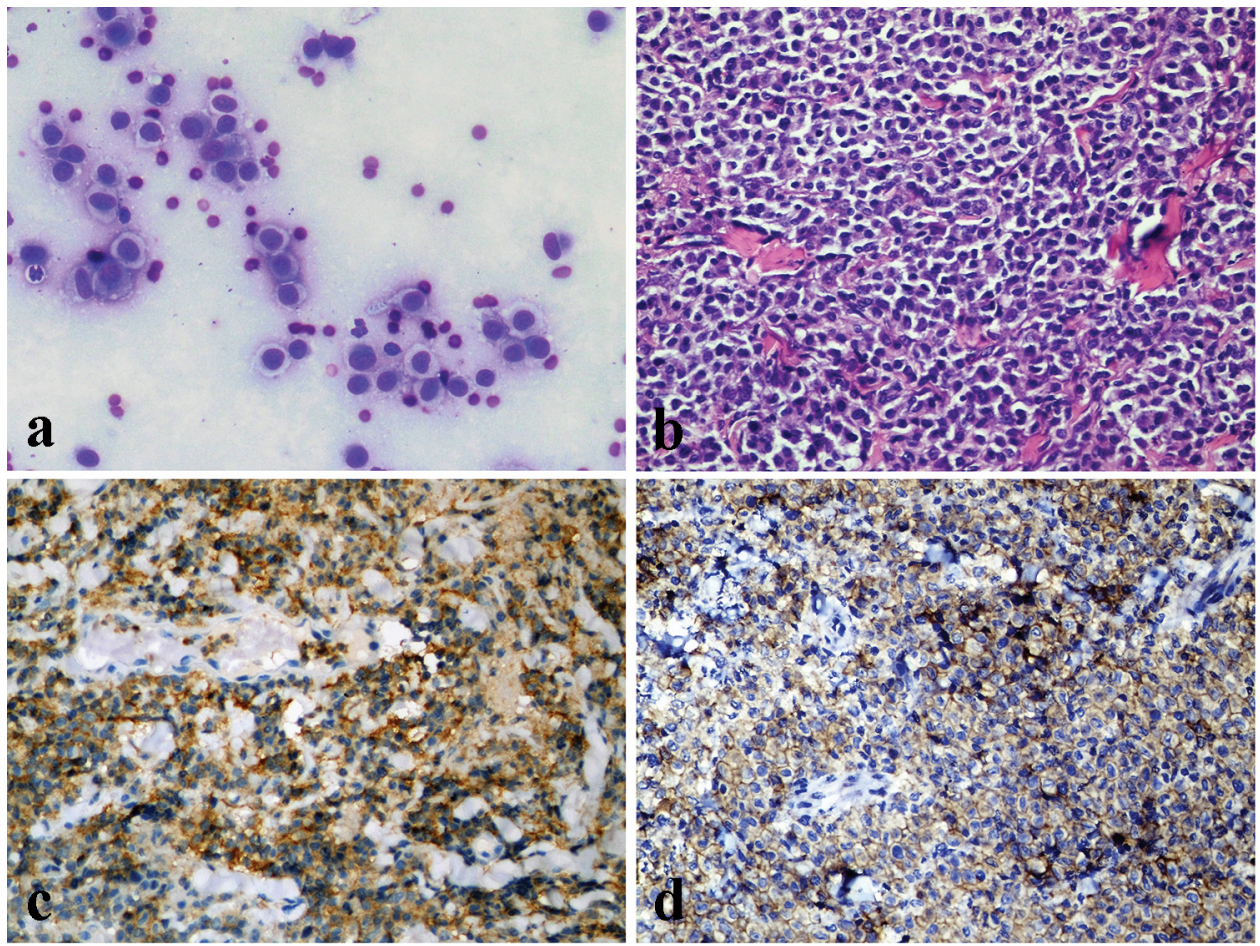

Figure 4. Histiocytoma. (a) Round-oval cells having prominent grey cytoplasm, Hemacolor, x200. (b) Numerous histiocytes proliferations in the dermis, Haematoxylin-Eosin, x400. (c) CD18 positivity in tumoral cells and (d) E-cadherin positivity in the borders of tumoral cells, avidin-biotin complex method, DAB chromogen, $\mathrm{x} 400$.

Cytologically, a malignant mesenchymal tumor was diagnosed in a case, but the diagnosis was changed as fibroepithelial polyp by histopathology. In another case, cytologically a fibropapilloma was diagnosed, but histopathologically fibroepithelial polyp was diagnosed. In one case cytological diagnosis of hemangiosarcoma was changed as hematoma in histopathology. In the cytological examination of a case, benign mesenchymal tumour was diagnosed, however histopathologically, granulation tissue formation was diagnosed. In a case, cytological inflammatory reaction diagnosis was changed as sebaceous hyperplasia in histopathology.

In two cases, epidermal inclusion cysts were cytologically diagnosed and these diagnoses were changed as epidermoid cyst by histopathology. 


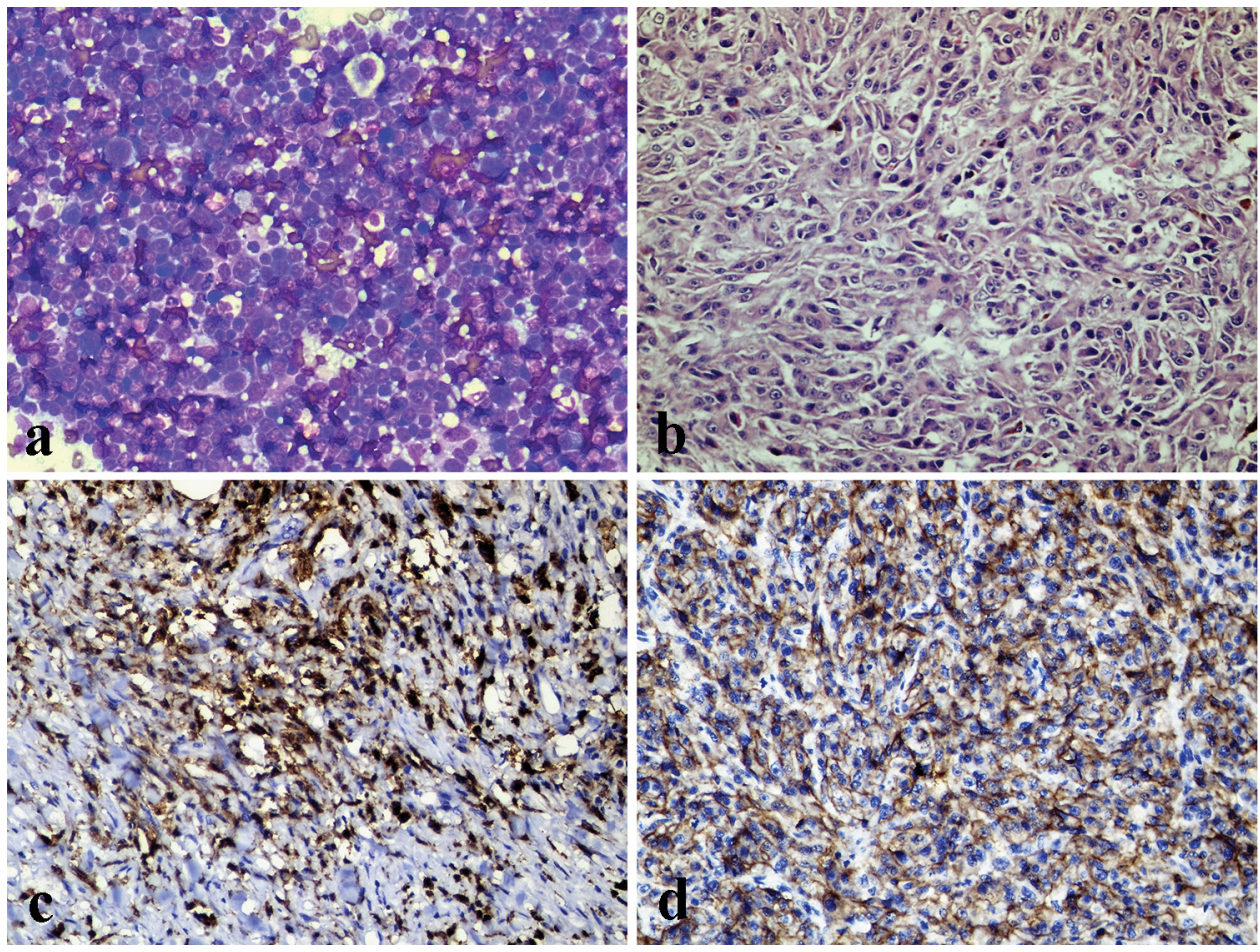

Figure 5. Histiocytic sarcoma. (a) Round-oval cells showing prominent anisokaryosis, Hemacolor, x200. (b) Round-oval and spindle-shaped atypical cells, Haematoxylin-Eosin, x400. (c) CD204 positivity in tumoral cells and (d) E-cadherin positivity of the borders of tumoral cells, avidin-biotin complex method, DAB chromogen, $\mathrm{x} 400$.

\section{Comparison of histopathological and immunohistochemical findings}

All tumoral cases except melanocytic tumors and lipomas were stained immunohistochemically. The histopathological diagnoses were confirmed in 40 tumors, but changed in six cases, all of which were of mesenchymal descent.

Cytokeratin and vimentin immunohistochemical stainings were used for all epithelial tumors. All cases were positive for cytokeratin and negative for vimentin except one sebaceous adenocarcinoma case, where both cytokeratin and vimentin were positively stained (Figs. 1c and 1d). Histopathological and immunohistochemical diagnoses were compatible for all epithelial tumors.

CD31, CD204, cytokeratin, desmin, Melan-A, neurofilament, S100, sarcomeric actin, smooth muscle actin, and vimentin antibodies were used for the diagnosis of mesenchymal tumors, except two hemangioma cases where only CD31 positivity was considered sufficient due to the typical histopathological appearance. All histiocytic sarcomas were positive for CD18, CD204 (Fig. 5c), E-cadherin (Fig. 5d) and vimentin, but negative for CD3, CD20, and tryptase. Final diagnosis of these cases was made as histiocytic sarcoma. 

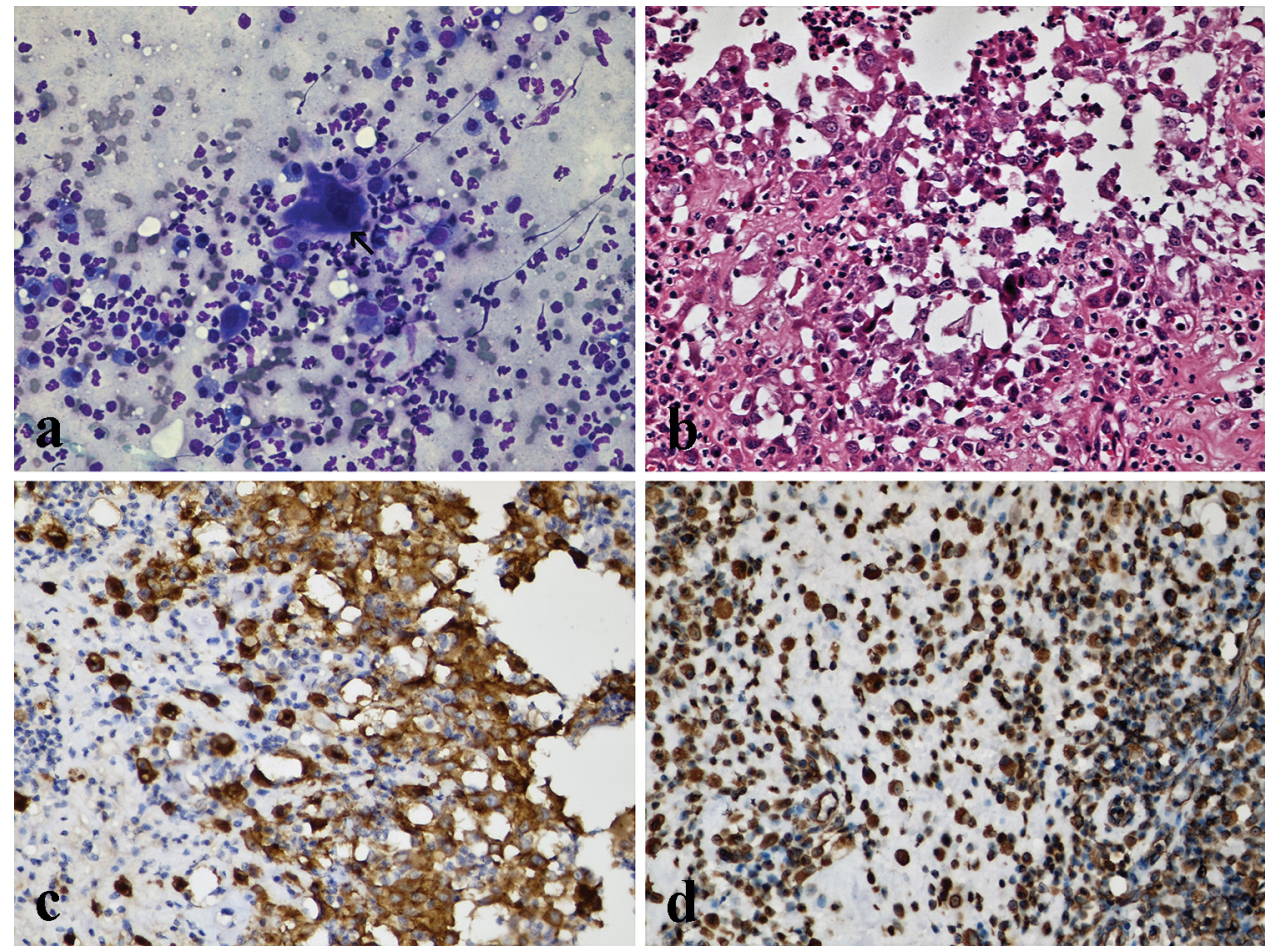

Figure 6. Malignant histiocytosis. (a) Inflammatory cells, large histiocytes, and multinucleated giant cell (arrow), Hemacolor, x200. (b) Pleomorphic histiocytes with distinct nucleolus, rounded nuclei, and multiple nuclei observed as clusters, Haematoxylin-Eosin, x200. (c) CD204 and (d) vimentin positive histiocytes, avidin-biotin complex method, DAB chromogen, $\mathrm{x} 400$.

All mesenchymal tumors were negative for cytokeratin and positive for vimentin. In one case with a histopathological diagnosis of fibroma, positivity was observed for S100, sarcomeric actin, and vimentin, and the final diagnosis was made as rhabdomyoma. One of the three histopathologically diagnosed perivascular wall tumors was positive for S100 and vimentin, and the diagnosis was changed as hemangiopericytoma. Two other perivascular wall tumors were positive only for vimentin, therefore the diagnosis was redefined as undifferentiated sarcoma. In one case of undifferentiated sarcoma, tumor cells stained with anti-sarcomeric actin (Fig. 2c), SMA (Fig. 2d), and vimentin, so the final diagnosis was hemangiopericytoma. In another case which was histopathologically diagnosed as haemangioma, tumor cells were negative for CD31 and all other mesenchymal markers except vimentin, and the final diagnosis was defined as benign mesenchymal tumor.

The antibodies used for the immunohistochemical diagnosis of round cell tumors were as follows: tryptase for mast cell tumours; CD3, CD18, CD20, E-cadherin, and tryptase for lymphomas; and CD3, CD18, CD20, CD204, E-cadherin, and vimentin for histiocytic tumors. All seven mastocytoma cases were confirmed after positive 
immunostaining with tryptase. CD18 positivity (Fig. 4c) together with CD3, CD20, CD204, and tryptase negativity were observed in all histiocytoma cases. E-cadherin positivity (Fig. 4d) was seen only in one histiocytoma case and, therefore, a Langerhans cell origin was suspected. In a malignant histiocytosis case, CD18, CD204 (Fig. 6c), E-cadherin and vimentin (Fig. 6d) positivity were observed and the diagnosis was confirmed.

One histopathologically diagnosed lymphoma case was positive for CD3 and CD18, but negative for CD20, E-cadherin, and tryptase, and a final diagnosis was made as T-cell lymphoma. The other lymphoma case was positive for CD18, but negative for CD3, CD20, E-cadherin and tryptase, and the final diagnosis in this case was considered as null-lymphoma.

Compatibility rate of histopathological and immunohistochemical diagnoses were found as $86.6 \%$. All control tissues were positive in terms of the relative cell components. Additionally, some tumoral cases were used as self-control tissue for normal components on the slides. All negative control slides were negative for used antibodies.

\section{Accuracy of cytology in characterizing benign/malignant nature}

In order to determine the accuracy of cytological diagnosis in defining benignancy/ malignancy, cytological and immunohistochemical staining results were compared because benign/malignant differentiation of some cases could be possible after immunohistochemistry. Non-tumoral lesions were considered as benign formations. The values were calculated as follows: sensitivity (true positive rate) $=76 \%$, specificity (true negative rate $)=86.9 \%$, positive predictive value $=76 \%$, negative predictive value $=86.9 \%$, total accuracy rate $=83 \%($ Table 7$)$.

Table 7. Number of cases for benign-malignant comparison

\begin{tabular}{lccc}
\hline \multirow{2}{*}{ Cytological diagnosis } & \multicolumn{3}{c}{ Histopathological diagnosis* } \\
\cline { 2 - 4 } & Malignant & Benign or non-tumoral & Total \\
\hline Malignant & $19(\mathrm{TP})$ & $6(\mathrm{FP})$ & 25 \\
Benign or non-tumoral & $6(\mathrm{FN})$ & $40(\mathrm{TN})$ & 46 \\
Total & 25 & 46 & $71(\mathrm{~N})$ \\
\hline
\end{tabular}

*TP: True positive, FP: False positive, FN: False negative, TN: True negative Accuracy rate: $83.1 \%(\mathrm{TP}+\mathrm{TN} / \mathrm{N})$

\section{Accuracy of cytology in the specific-general diagnosis of tumors}

For the evaluation of the accuracy rate for specific and general diagnosis between cytology and histopathology, statistical analysis was performed. Specific diagnosis such as hemangioma, lipoma, trichoblastoma, mastocytoma etc. and general diagnosis such 
as benign mesenchymal tumor, malignant mesenchymal tumor, carcinoma etc. were compared. All changing diagnosis were evaluated in this statistical comparison without considering diagnostic accordance for the character of the tumor. The values were calculated as follows: sensitivity (true positive rate) $=73.4 \%$, specificity (true negative rate $)=40.9 \%$, positive predictive value $=70.5 \%$, negative predictive value $=40.9 \%$, total accuracy rate $=63.3 \%$ (Table 8$)$.

Table 8. Number of cases for specific and general diagnoses*

\begin{tabular}{lccc}
\hline \multirow{2}{*}{ Cytological diagnosis } & \multicolumn{3}{c}{ Histopathological diagnosis } \\
\cline { 2 - 4 } & Specific diagnosis & General diagnosis & Total \\
\hline Specific diagnosis & $36(\mathrm{TP})$ & $13(\mathrm{FP})$ & 51 \\
General diagnosis & $13(\mathrm{FN})$ & $9(\mathrm{TN})$ & 22 \\
Total & 49 & 22 & 71 \\
\hline
\end{tabular}

TP: True positive, FP: False positive, FN: False negative, TN: True negative

* Specific diagnosis: Exact diagnosis such as squamous cell carcinoma or haemangiopericytoma

General diagnosis. Broad diagnosis such as benign mesenchymal tumor or carcinoma

Accuracy rate: $63.4 \%(\mathrm{TP}+\mathrm{TN} / \mathrm{N})$

\section{DISCUSSION}

Cytology is a quick and reliable tool in most pathology laboratories. In dogs, the accuracy of cytological diagnoses was tested in various studies yielding different accuracy rates $[1,10,12-14]$. Cohen et al. [10] evaluated 269 masses cytologically and histopathologically and $63.2 \%$ accuracy rate was calculated when insufficient samples were excluded. Ghisleni et al. [12] have compared the cytological and histopathological findings of 292 palpable cutaneous and subcutaneous masses in 242 dogs and 50 cats between 1999-2003. As a result, $90.9 \%$ of the cases showed agreement between cytological diagnosis and histopathological diagnosis. In another retrospective study conducted by Simeonov [14], the cytological preparations of 300 cutaneous and subcutaneous palpable lesions of dogs were compared with histopathological slides and total agreement rate between cytology and histopathology was $88.7 \%$.

It should be noted that changes in the nomenclature of tumors in time and failure to use standardized criteria may lead to controversies in histological diagnosis, which naturally affects compliance with cytological diagnosis [24-26]. In our study, histopathological diagnoses were made according to the previous tumor classifications and additional immunohistochemical stainings were performed in order to eliminate the above mentioned disputes.

In our study, a mesenchymal malignant tumor, a haemangiosarcoma, and an adenocarcinoma were misdiagnosed in cytology and diagnoses were changed as fibroepithelial polyp, organizing haematoma and chronic granulomatous inflammation, respectively. It is difficult to distinguish well-differentiated haemangiosarcomas from benign haemangiomas and/or haematomas (which form reactive fibroblasts in the 
wall), and histological examination is often necessary for the definitive diagnosis [27]. It has been reported that inflammation can induce dysplastic changes and such cases can be misinterpreted as a tumor [2]. Large epithelioid macrophages and proliferating fibroblasts are commonly observed in inflammatory lesions and these cells can be similar to malignant tumor cells. Also squamous cells, fibroblasts, and transitional epithelial cells can exhibit marked anisonucleosis, distinct nucleoli, mitotic figures, and variations in nucleus:cytoplasm ratio, features all of which can be confused with tumor cell features $[2,28]$.

In the study of Simeonov [14], 19 cases with a diagnosis of inflammation in cytology were diagnosed as tumor in histopathology. It should be remembered that inflammation can coexist in tumors [29]. In our study, cytological diagnoses of five inflammatory reactions were changed as a papilloma, a sebaceous adenoma, a sebaceous hyperplasia, and two squamous cell carcinomas after histopathology. This demonstrates the importance of careful examination of tumors with concurrent inflammatory reaction.

Origin of melanocytic tumors was determined accurately in cytology by observing dense melanin pigmentation. In our study, one case of melanocytoma diagnosis in cytology was changed as malignant melanoma in histopathology. The reason of this incompatibility was difficulty of nuclear malignancy evaluation due to dense pigmentation. In the study of Simeonov [14], all melanocytic tumor diagnoses in cytology were confirmed with histopathology. In that study, tumor character was not evaluated in cytology, but all cases were diagnosed as benign in histopathology. In our study, malignancy could be evaluated in other cases due to the low pigmentation of cells in cytology.

We did not subclassify mesenchymal tumors cytologically in most cases in our study. Instead, they were classified as benign or malignant mesenchymal tumors in nine cases, and these diagnoses were consistent with the final diagnoses. Similarly, Ghisleni et al. [12] reported that cytomorphology was inadequate for determining the cell type in 45 of $69(67.2 \%)$ mesenchymal tumors and these cases were defined as sarcoma. In Simeonov's study [14], 33 of the mesenchymal tumors could not be subclassified, of which 25 were later identified as fibrosarcoma, five as liposarcoma, two as osteosarcoma, and one as myxosarcoma.

Mesenchymal tumors comprise $8-15 \%$ of canine cutaneous and subcutaneous tumors and are formed mostly by spindle-shaped cells [30]. Differential diagnosis of these tumors is difficult due to similar morphological patterns [17,20]. Immunohistochemically vimentin expression is suggestive of a mesenchymal origin [31]. In accordance with this, all mesenchymal tumors were vimentin positive in our study. Even with additional immunohistochemical diagnostic markers, a mesenchymal tumor origin may not always be determined [19,32]. An immunohistochemical panel for definitive differentiation of mesenchymal tumors has not been defined yet [33]. Due to this ambiguity, sometimes these tumors are named as spindle cell tumors of the soft tissue $[31,34,35]$. In our study, an exact diagnosis could not be reached in two mesenchymal tumors and these 
tumors were diagnosed as undifferentiated sarcoma. Histopathologic diagnosis of two perivascular wall tumors were undifferentiated sarcoma after immunohistochemistry due to vimentin positivity alone. Additionally, a case of haemangioma was negative for all markers except vimentin and the final diagnosis was changed as benign mesenchymal tumor depending on the histopathological pattern.

In our study, vimentin and S100 positivity were observed in cases histopathologically diagnosed as myxoid PNST (Figs. 3c and 3d) and perineuroma. GFAP and S100 are suggested as useful markers for the diagnosis of PNSTs [20]. Peripheral nerve sheath tumors originate from Schwann cells, modified Schwann cells, fibroblasts or perineural cells [36]. Haemangiopericytoma should be primarily considered in the differential diagnosis of PNSTs. Especially, the perivascular spiral pattern is characteristic for haemangiopericytomas. These patterns have also been observed in PNSTs especially around collagen fibres instead of capillaries [31]. Similarly, we observed these patterns around nerve fascicles which included fine collagen fibres in the case of perineuroma and these areas were positive for S100. Although high positivity rates have been reported with neurofilament [37], in our study neurofilament immunostaining was negative in all cases.

Chijiwa et al. [32] reported that $\alpha$-SMA may be useful for differentiation of PNSTs and hemangiopericytomas. They observed that 17 PNSTs were negative and five hemangiopericytomas were positive for $\alpha$-SMA. In another study which involved cases of hemangiopericytoma, leiomyosarcoma, and hemangiosarcoma, $\alpha$-SMA was positive in six of 18 hemangiopericytomas [38]. We observed $\alpha$-SMA positivity in only one case which was histopathologically diagnosed as undifferentiated sarcoma. In this case, vimentin and sarcomeric actin were also positive, thus the diagnosis was changed as hemangiopericytoma. In another case diagnosed as perivascular wall tumor in histopathology, vimentin and S100 positivities were seen. Due to some reports mentioning S100 positivity in peripheral wall tumors [17,32] and the observation of a whirling pattern in our case, the final diagnosis was made as hemangiopericytoma.

Malignant fibrous histiocytoma is in the "fibrohistiocytic" category according to the 2002 WHO Classification [39]. In humans, malignant fibrous histiocytoma is classified as storiform-pleomorphic, giant cell, inflammatory, myxoid, and angiomatoid type according to the common cell type [40]. However, only three types have been reported in domestic animals [41] and these types were reclassified as undifferentiated pleomorphic sarcoma in the new classification [39]. In our study, CD3, CD18, CD20, CD204, E-cadherin, tryptase, and vimentin immunostaining was performed for the differentiation of malignant fibrous histiocytoma from histiocytic sarcoma. Negativity of CD3, CD18, CD20, E-cadherin, but positivity with CD204 and vimentin were observed. While canine histiocytic sarcomas are regularly CD18 positive and mostly vimentin negative, malignant fibrous histiocytomas have a vimentin positive and CD18 negative phenotype [41-43]. Ko et al. [44] performed $\alpha$-SMA, CD68, desmin, S100 and vimentin in three canine malignant fibrous histiocytomas and they observed positivity for vimentin, positivity in only giant cells for CD68, and negativity for $\alpha$-SMA, desmin, 
and S100. These researchers suggest that even only vimentin positivity without any other special markers is useful for the diagnosis of malignant fibrous histiocytoma. Similarly, in our mentioned case, due to the negativity of CD18 and positivity of vimentin and CD204, a diagnosis of malignant fibrous histiocytoma was made.

In one study, the accuracy of cytology in round cell tumors has been found to be less than 50\% [10]. Ghisleni et al. [12] also reported that there were certain limitations in determining the origin and benignancy/malignancy of 10 round cell tumors. In our study, cytological diagnoses of mastocytomas, and histiocytomas were confirmed in all cases. Mastocytoma diagnosis is generally considered simple due to distinct cytoplasmic granules $[8,45,46]$, and high accuracy rates between cytology and histopathology have been reported $[12,14]$. Although certain studies report high accuracy rates for cytological diagnosis of histiocytomas [12,47], some histiocytic tumors cannot be differentiated from other round cell tumors (lymphoma, plasmacytoma) and only a round cell tumor diagnosis can be made with cytology $[12,14,45]$. Distinguishing histiocytic sarcoma from lymphoma and plasmacytoma can also be difficult [47].

In canine cutaneous round cell tumors, histopathology is generally not sufficient for the exact diagnosis and immunohistochemical stainings should also be utilized [48]. CD18, E-cadherin, and MHC-II have been suggested as useful markers for the immunohistochemical diagnosis of histiocytic tumors. Furthermore, CD3 and CD79 have been suggested as markers for the differentiation of $\mathrm{B}$ and $\mathrm{T}$ cell lymphomas $[42,47,49]$. Fernandez et al. [48] examined 72 canine cutaneous round cell tumors and used tryptase, chymase, and serotonin for mast cells; CD1a, CD18, and MHC-II for histiocytes; CD3 for T lymphocytes; and CD79a for B lymphocytes and plasma cells. We used only tryptase for mastocytomas; CD3, CD18, and CD20 for lymphomas; CD18, CD204, E-cadherin, and vimentin for histiocytic tumors. CD18 was used for differentiation of malignant fibrous histiocytoma from histiocytic sarcoma. Tryptase positivity was deemed sufficient in diagnosis of mastocytomas, and no further immunohistochemical stainings were performed to keep costs low.

For differentiation of canine lymphomas from other round cell tumors, immunohistochemical staining should be performed in many cases [49]. In our study, one lymphoma case revealed CD3 and CD18 positivity and the final diagnosis was made as $\mathrm{T}$ cell lymphoma. In other case which was diagnosed as lymphoma, positivity of CD18 and negativity of CD3 and CD20 were observed. CD18 is a formalinresistant integrin molecule on the surface of leukocytes and dendritic cells originating from bone marrow. For this reason, CD18 (or MHC-II) positive and CD3 or CD79a negative tumoral cells are considered as of a histiocytic origin $[42,43,47,50]$. However, atypical immunophenotype of tumor cells have also been reported rarely [51,52]. As an example null lymphomas do not express CD3 and CD79a or light and heavy chains of immunoglobulins [53-55].

Null lymphoma has been rarely reported in dogs. This tumor has been suggested to have a "natural killer" cell origin [53]. CD3 and CD79a negativity of these tumors does 
not necessarily mean that these are not lymphoma. Granularity feature of tumoral cells may be useful for diagnosis, but additional immunohistochemical staining may also be needed [56]. Therefore, we performed E-cadherin and tryptase in the case of nulllymphoma and these two markers were found negative.

In our study CD18 was used for the determination of leukocytic origin and all round cell tumors showed positivity. Unlike a previous report [21], we observed E-cadherin positivity in only one histiocytoma case, but not in other three histiocytomas. In dogs, E-cadherin is a marker used for histiocytomas [57,58], but not a specific marker for Langerhans cells [21]. Pazdzior-Czapula et al. [47] showed limited positivity for CD18, E-cadherin, and MHC-II expressions in canine cutaneous histiocytomas. They suggested that E-cadherin has limited value for the diagnosis of cutaneous histiocytomas. According to Valli et al. [51], Langerhans cells are unique cells which express E-cadherin. However, according to some other studies, due to its expression in plasmacytomas and epitheliotropic lymphomas, E-cadherin is not considered a unique marker for Langerhans cells and it cannot be used for the exact differentiation of canine cutaneous round cell tumors [47,59].

It has been reported that canine histiocytic sarcomas express CD1, CD11c, CD18, CD45 and MHC-II but not express E-cadherin [18] and these tumors originated from dendritic cells $[21,42]$. In another study, because of E-cadherin positivity in two histiocytic sarcomas, it was thought that Langerhans cell origin of these tumors [47]. Hirako et al. [60] reported that primary cutaneous histiocytic sarcoma originated from Langerhans cells in a male Pembroke Welsh Corgi dog. They showed immunopositivity for vimentin, HLA-DR antigen, Iba1, CD18 and E-cadherin, thus they suggested Langerhans cell origin due to the E-cadherin positivity. In our study, E-cadherin positivity was observed in three histiocytic sarcomas. Furthermore, CD18, CD204 and vimentin positivity were observed in same cases.

\section{CONCLUSION}

As a result of our study, we suggest that cytopathology is a reliable and quick technique with high accuracy rate $(84.5 \%$ for tumoral/non-tumoral comparison and $83 \%$ for comparison of benignancy/malignancy) as compared to histopathology. The main diagnostic challenge in cytology is the mesenchymal tumor. Even histopathology is not sufficient for the accurate diagnosis of mesenchymal and round cell tumors, and specific immunohistochemical panels should be performed for accurate diagnosis. Furthermore, histopathology is the method that confirms or refutes the cytopathological diagnosis, and also guides the immunohistochemistry in some cases.

\section{Acknowledgements}

This study was performed as part of the PhD study of Volkan Ipek. Financial support was provided by Bursa Uludag University Scientific Research Funds (Project Grant No: $\operatorname{KUAP}(V)-2014 / 42)$. 


\section{Authors' contributions}

IV prepared and examined cytological, histopathological and immunohistochemical slides, made statistical evaluation and wrote the manuscript. CIT and AA evaluated histopathological and immunohistochemical slides and contributed to writing the manuscript.

\section{Declaration of conflicting interests}

The author(s) declared no potential conflicts of interest with respect to the research, authorship, and/or publication of this article.

\section{REFERENCES}

1. Vos JH, van den Ingh TSGAM, van Mil FN: Non-exfoliative canine cytology: The value of fine needle aspiration and scraping cytology. Vet Q 1989, 11:222-31.

2. Tyler R, Cowell R, Baldwin C, Morton R: Introduction. In: Cowell R, Tyler R, Meinkoth J, editors. Diagnostic Cytol Hematol dog cat 2nd ed. St. Louis: Mosby; 1999. p. 1-19.

3. Valenciano AC, Burton A, Borchers A, Cowell RL: Cytology of Cutaneous and Subcutaneous Lesions. Equine Hematol Cytol Clin Chem Wiley; 2021. p. 161-93.

4. el Hag IA, Chiedozi LC, al Reyees FA, Kollur SM: Fine needle aspiration cytology of head and neck masses. Seven years' experience in a secondary care hospital. Acta Cytol Karger Publishers; 2003, 47:387-92.

5. Ko H, Jhu I, Yang S, Lee J, Nam J, Juhng S, et al.: Clinicopathologic Analysis of Fine Needle Aspiration Cytology of the Thyroid A Review of 1, 613 Cases and Correlation with Histopathologic Diagnoses. 2003, :727-32.

6. Choi YD, Choi YH, Lee J, Nam JH, Juhng S, Choi C: Analysis of Fine Needle Aspiration Cytology of the Breast A Review of 1,297 Cases and Correlation with Histologic Diagnoses. 2004, :801-6.

7. Romano M, Griffo S, Gentile M, Mainenti PP, Tamburrini O, Iaccarino V, et al.: CT guided percutaneous fine needle biopsy of small lung lesions in outpatients. Safety and efficacy of the procedure compared to inpatients. Radiol Med 2004, 108:275-82.

8. Griffiths GL, Lumsden JH, Valli VEO: Fine Needle Aspiration Cytology and Histologic Correlation in Canine Tumors. Vet Clin Pathol Wiley/Blackwell (10.1111); 1984, 13:13-7.

9. Chalita MC, Matera JM, Alves MT, Longatto Filho A: Nonaspiration fine needle cytology and its histologic correlation in canine skin and soft tissue tumors. Anal Quant Cytol Histol 2001, 23:395-9.

10. Cohen M, Bohling MW, Wright JC, Welles EA, Spano JS: Evaluation of sensitivity and specificity of cytologic examination: 269 cases (1999-2000). J Am Vet Med Assoc 2003, 222:964-7.

11. Simon D, Schoenrock D, Nolte I, Baumg W, Barron R: Cytologic examination of fine-needle aspirates from mammary gland tumors in the dog : diagnostic accuracy with comparison to histopathology and association with postoperative outcome. 2009, 4:521-8.

12. Ghisleni G, Roccabianca P, Ceruti R, Stefanello D, Bertazzolo W, Bonfanti U, et al.: Correlation between fine-needle aspiration cytology and histopathology in the evaluation of 
cutaneous and subcutaneous masses from dogs and cats. Vet Clin Pathol Wiley/Blackwell (10.1111); 2006, 35:24-30.

13. Eich C, Whitehair J, Moroff S, Heeb L: The accuracy of intraoperative cytopathological diagnosis compared with conventional histopathological diagnosis. J Am Anim Hosp Assoc 2000, 36:16-8.

14. Simeonov RS: The accuracy of fine-needle aspiration cytology in the diagnosis of canine skin and subcutaneous masses. Comp Clin Path Springer-Verlag; 2012, 21:143-7.

15. Skeldon N, Dewhurst E: The perceived and actual diagnostic utility of veterinary cytological samples. J Small Anim Pract Wiley/Blackwell (10.1111); 2009, 50:180-5.

16. Goldschmidt M, Dunstan R, Stannard A: Histological classification of epithelial and melanocytic tumors of the skin of domestic animals, 2nd edition. Washington DC: Armed Forces Institute of Pathology; 1998.

17. Hendrick M, Mahaffeey E, Moore F, Vos J, Walder E: Histological classification of mesenchymal tumors of skin and soft tissues of domestic animals, Vol. 2. Washington DC: Armed Forces Institute of Pathology; 1998.

18. Gross T, Ihrke P, Walder E, Affolter V: Skin diseases of the dog and cat: clinical and histopathologic diagnosis. 2nd ed. Oxford: Blackwell; 2005.

19. Avallone G, Helmbold P, Caniatti M, Stefanello D, Nayak RC, Roccabianca P: The Spectrum of Canine Cutaneous Perivascular Wall Tumors: Morphologic, Phenotypic and Clinical Characterization. Vet Pathol SAGE PublicationsSage CA: Los Angeles, CA; 2007, 44:607-20.

20. Goldschmidt M, Hendrick M: Tumors of the skin and soft tissues. In: Meuten D, editor. Tumors Domest Anim 4th ed. Ames, Iowa: Iowa State Univ Pr; 2002. p. 109-11.

21. Moore PF: A Review of Histiocytic Diseases of Dogs and Cats. Vet Pathol SAGE PublicationsSage CA: Los Angeles, CA; 2014, 51:167-84.

22. Zhu W, Zeng N, Wang N: Sensitivity, specificity, accuracy, associated confidence interval and ROC analysis with practical SAS ${ }$ implementations. Northeast SAS Users Gr 2010 Heal Care Life Sci 2010, :1-9.

23. Sinna EA, Ezzat N: Diagnostic accuracy of fine needle aspiration cytology in thyroid lesions. J Egypt Natl Canc Inst Elsevier; 2012, 24:63-70.

24. Aitken M, Patnaik A: Comparison of needle-core (Trucut) biopsy and surgical biopsy for the diagnosis of cutaneous and subcutaneous masses: a prospective study of 51 cases (November 1997-August 1998). J Am Anim Hosp Assoc 2000, 36:153-7.

25. Willard MD, Lovering SL, Cohen ND, Weeks BR: Quality of tissue specimens obtained endoscopically from the duodenum of dogs and cats. J Am Vet Med Assoc American Veterinary Medical Association 1931 North Meacham Road, Suite 100 Schaumburg, IL 60173 USA; 2001, 219:474-9.

26. Willard MD, Jergens AE, Duncan RB, Leib MS, McCracken MD, DeNovo RC, et al.: Interobserver variation among histopathologic evaluations of intestinal tissues from dogs and cats. J Am Vet Med Assoc 2002, 220:1177-82.

27. Shelly S: Cutaneous lesions. Vet Clin North Am 2003, 33:1-46.

28. Sharkey LC, Dial SM, Matz ME: Maximizing the Diagnostic Value of Cytology in Small Animal Practice. Vet Clin North Am Small Anim Pract Elsevier; 2007, 37:351-72.

29. Duncan JR, Prasse KW: Cytologic examination of the skin and subcutis. Vet Clin North Am 1976, 6:637-45. 
30. Dobson JM, Samuel S, Milstein H, Rogers K, Wood JLN: Canine neoplasia in the UK: estimates of incidence rates from a population of insured dogs. J Small Anim Pract Wiley/ Blackwell (10.1111); 2002, 43:240-6.

31. Gaitero L, Añor S, Fondevila D, Pumarola M: Canine Cutaneous Spindle Cell Tumours with Features of Peripheral Nerve Sheath Tumours: A Histopathological and Immunohistochemical Study. J Comp Pathol W.B. Saunders; 2008, 139:16-23.

32. Chijiwa K, Uchida K, Tateyama S: Immunohistochemical Evaluation of Canine Peripheral Nerve Sheath Tumors and Other Soft Tissue Sarcomas. Vet Pathol SAGE PublicationsSage CA: Los Angeles, CA; 2004, 41:307-18.

33. Dennis MM, McSporran KD, Bacon NJ, Schulman FY, Foster RA, Powers BE: Prognostic Factors for Cutaneous and Subcutaneous Soft Tissue Sarcomas in Dogs. Vet Pathol SAGE PublicationsSage CA: Los Angeles, CA; 2011, 48:73-84.

34. Williamson MM, Middleton DJ: Cutaneous soft tissue tumours in dogs: classification, differentiation, and histogenesis. Vet Dermatol Wiley/Blackwell (10.1111); 1998, 9:43-8.

35. Chase D, Bray J, Ide A, Polton G: Outcome following removal of canine spindle cell tumours in first opinion practice: 104 cases. J Small Anim Pract 2009, 50:568-74.

36. Koestner A, Higgins R: Tumors of the nervous system. In: Meuten D, editor. Tumors Domest Anim 4th ed. Ames: Iowa State Press; 2002. p. 697-738.

37. Schöniger S, Summers BA: Localized, Plexiform, Diffuse, and Other Variants of Neurofibroma in 12 Dogs, 2 Horses, and a Chicken. Vet Pathol SAGE PublicationsSage CA: Los Angeles, CA; 2009, 46:904-15.

38. Fujii Y, Tsuchiya T, Morita R, Kimura M, Suzuki K: Tumour Endothelial Marker-1 is Expressed in Canine Haemangiopericytomas. J Comp Pathol Elsevier Ltd; 2013, 149:17281.

39. Fletcher CD, Unni KK, Mertens F: Pathology and Genetics of Tumours of Soft Tissue and Bone. In: Kleihues P, Sobin LH, editors. World Heal Organ Classif Tumours Lyon: IARC Press; 2002. p. 109-25.

40. Al-Agha OM, Igbokwe AA: Malignant fibrous histiocytoma: between the past and the present. Arch Pathol Lab Med 2008, 132:1030-5.

41. Morris JS, McInnes EF, Bostock DE, Hoather TM, Dobson JM: Immunohistochemical and Histopathologic Features of 14 Malignant Fibrous Histiocytomas from Flat-Coated Retrievers. Vet Pathol 2002, 39:473-9.

42. Affolter VK, Moore PF: Localized and Disseminated Histiocytic Sarcoma of Dendritic Cell Origin in Dogs. Vet Pathol SAGE PublicationsSage CA: Los Angeles, CA; 2002, 39:74-83.

43. Craig LE, Julian ME, Ferracone JD: The Diagnosis and Prognosis of Synovial Tumors in Dogs: 35 Cases. Vet Pathol SAGE PublicationsSage CA: Los Angeles, CA; 2002, 39:66-73.

44. Ko JS, Kim HJ, Choi YM, Kim JW, Park C, Do SH: Diagnostic approach to malignant fibrous histiocytomas of soft tissue in dogs : a case report. 2013, 2013:621-7.

45. Ménard M, Fontaine M, Morin M: Fine needle aspiration biopsy of malignant tumors in dogs and cats: a report of 102 cases. Can Vet J = La Rev Vet Can Canadian Veterinary Medical Association; 1986, 27:504-10.

46. Jackson DE, Selting KA, Spoor MS, Henry CJ, Wiedmeyer CE: Evaluation of fixation time using Diff-Quik for staining of canine mast cell tumor aspirates. Vet Clin Pathol Wiley/ Blackwell (10.1111); 2013, 42:99-102. 
47. Paździor-Czapula K, Rotkiewicz T, Otrocka-Domagała I, Gesek M, Śmiech A: Morphology and immunophenotype of canine cutaneous histiocytic tumours with particular emphasis on diagnostic application. Vet Res Commun Springer Netherlands; 2015, 39:7-17.

48. Fernandez NJ, West KH, Jackson ML, Kidney BA: Immunohistochemical and Histochemical Stains for Differentiating Canine Cutaneous Round Cell Tumors. Vet Pathol SAGE PublicationsSage CA: Los Angeles, CA; 2005, 42:437-45.

49. Cangul IT, van Garderen E, van der Linde-Sipman JS, van den Ingh TSGAM, Schalken JA: Canine Balloon and Signet-ring Cell Melanomas: a Histological and Immunohistochemical Characterization. J Comp Pathol 2001, 125:166-73.

50. Constantino-Casas F, Mayhew D, Hoather TM, Dobson JM: The Clinical Presentation and Histopathologic-Immunohistochemical Classification of Histiocytic Sarcomas in the Flat Coated Retriever. Vet Pathol SAGE PublicationsSage CA: Los Angeles, CA; 2011, 48:764-71.

51. Valli V, Jacobs R, Parodi A: Solid myeloid proliferations. In: Valli V, editor. WHO Int Classif tumors Domest Anim Histol Classif Hematop tumors Domest Anim Second Ser vol 8 Washington DC: Armed Forces Institute of Pathology; 2002. p. 58-61.

52. Valli V: Histiocytoses. In: Valli V, editor. Vet Comp Hematop Ames: Blackwell publishing; 2007. p. 505-21.

53. Ruslander DA, Gebhard DH, Tompkins MB, Grindem CB, Page RL: Immunophenotypic characterization of canine lymphoproliferative disorders. In Vivo 1997, 11:169-72.

54. Turinelli V, Marchal T, Ponce F, Bonnefont-Rebeix C, Fournel-Fleury C: Aggressive large granular lymphocyte lymphomas in five dogs: a clinical cytohistological and immunological study. Comp Clin Path Springer-Verlag; 2005, 13:109-18.

55. Ponce F, Marchal T, Magnol JP, Turinelli V, Ledieu D, Bonnefont C, et al.: A Morphological Study of 608 Cases of Canine Malignant Lymphoma in France With a Focus on Comparative Similarities Between Canine and Human Lymphoma Morphology. Vet Pathol SAGE PublicationsSage CA: Los Angeles, CA; 2010, 47:414-33.

56. Kariya K, Konno A, Ishida T: Perforin-like Immunoreactivity in Four Cases of Lymphoma of Large Granular Lymphocytes in the Cat. Vet Pathol 1997, 34:156-9.

57. Baines SJ, McInnes EF, McConnell I: E-cadherin expression in canine cutaneous histiocytomas. Vet Rec British Medical Journal Publishing Group; 2008, 162:509-13.

58. Pires I, Queiroga FL, Alves A, Silva F, Lopes C: Decrease of E-cadherin expression in canine cutaneous histiocytoma appears to be related to its spontaneous regression. Anticancer Res International Institute of Anticancer Research; 2009, 29:2713-7.

59. Ramos-Vara JA, Miller MA: Immunohistochemical Expression of E-cadherin Does Not Distinguish Canine Cutaneous Histiocytoma From Other Canine Round Cell Tumors. Vet Pathol SAGE PublicationsSage CA: Los Angeles, CA; 2011, 48:758-63.

60. Hirako A, Sugiyama A, Sakurai M, Ozaki K, Sakai H, Takeuchi T, et al.: Cutaneous histiocytic sarcoma with E-cadherin expression in a Pembroke Welsh Corgi dog. J Vet Diagnostic Investig SAGE PublicationsSage CA: Los Angeles, CA; 2015, 27:589-95. 


\title{
UPOREDNO ISPITIVANJE CITOLOŠKIH, HISTOPATOLOŠKIH I IMUNOHISTOHEMIJSKIH METODA DIJAGNOSTIKE KUTANIH I SUPKUTANIH MASA KOD PASA
}

\author{
IPEK Volkan, CANGUL I.Taci, AKKOC Ahmet
}

U studiji je urađena uporedna analiza citoloških, histopatoloških i imunohistohemijskih dijagnostičkih metoda ispitivanja kutanih i supkutanih masa kod 71 pasa. Citološka dijagnoza je obuhvatala 56 tumora (21 mezenhimskog porekla, 15 epitelnih, 16 tumora okruglih ćelija i četiri melanocitna tumora), 13 inflamatornih promena i dve ciste. Od dvadesetjednog mezenhimskog tumora, tri su kasnije potvrđena kao neneoplastične lezije, (hematomi, granulomatozno tkivo, fibroepitelijalni polip). Posle histopatoloških ispitivanja, trinaest od ukupno 15 epitelnih tumora, citološki su bili pravilno dijagnostikovani pri čemu su dva potvrđena kao neneoplastične tvorevine (fibroepitelni polip, granulaciono tkivo). Jedan mastocitom je kasnije potvrđen kao fibrozna hiperplazija. Dijagnoza je bila tačna u slučajevima tumora okruglih ćelija. Citološka dijagnoza je bila tačna u svim slučajevima melanotičnih tumora i cista. Pet slučajeva kod kojih je citološki nalaz ukazivao na zapaljenske reakcije, posle histopatološkog ispitivanja dijagnostikovani su kao tumori (limfom, papilom, sebaceozni adenom i skvamozni karcinom). Primenom imunohistohemijskih metoda, potvrđene su histopatološke dijagnoze svih epitelnih i tumora okruglih ćelija dok je dijagnoza šest mezenhimskih tumora promenjena posle ispitivanja imunohistohemijskim metodama. Tačnost citoloških ispitivanja u dijagnostici tumora i netumorskih tvorevina bila je $84,5 \%$, pri čemu je tačnost u određivanju benignog/malignog ponašanja tkiva bila $83 \%$. Usklađenost između histopatološkog i imunohistohemijskog rezultata bila je $86,6 \%$. Visok nivo tačnosti koji je dobijen na osnovu citoloških ispitivanja, dokazuje da je citološka metoda ispitivanja dobra početna dijagnostiča tehnika. Međutim i dalje je glavni izazov u dijagnostičkom smislu, ispitivanje mezenhimskih tumora kao i tumora praćenih inflamacijom. Rezultati ukazuju da imunohistohemijsko ispitivanje predstavlja osnovu dijagnoze većine mezenhimskih tumora. 